\title{
ADOPTION OF SOCIAL MEDIA FOR PUBLIC RELATIONS BY MUSEUMS
}

\section{Suzić, B., Karlíček, M., Stříteský, V.}

Conceptual evolution of the Internet and Web, substantiated through Web 2.0 and the emergence of online social networks, reinvented the way that enterprises interact with their customers. Museums, as cultural institutions with an important mission, are not unaffected by that change, however. In order to fulfil their duties and societal purpose successfully, they have to attract visitors' attention and engage the public effectively in a highly competitive and saturated environment. The goal of this paper is to analyze and compare the social media presence of museums in two European capitals. It focuses on museums in Prague and Berlin, and considers their general Web presence and the dynamics of activities on Facebook. In order to understand the integrative social media approach of museums in both regions, we investigated additionally Twitter and Youtube presence among museums with a Facebook account. The study reveals a lower presence of Prague museums both on the Web and in the identified social media networks, in comparison to Berlin museums. Moreover, we conclude that the presence of both regional museums on social media networks is low, while the integration and simultaneous application of more networks at the same time are negligible, both for Prague and Berlin museums.

Keywords: museums; Web 2.0; social media; Berlin museums; Prague museums JEL Classification: M30

\section{Introduction}

Social media emerged more than a decade ago, demonstrating a quick burst and rapid acceptance among consumers worldwide. The influence of online social networks in 2014 grew up to 1.59 billion of users, in the case of Facebook, and over 250 million of users on Twitter (Statista, 2015). The broad reach of social media encompasses both commercial, non-commercial and the personal sector, and it is becoming an integrative part of everyday life of many persons and core of the business processes among companies.

The importance of social media for business strategies is the subject of focus and analysis by many organizations, both commercial and academic ones. According to one of the recent reports dealing with social media ("Social Media Examiner", 2015), $92 \%$ of surveyed marketers declared the importance of social media to their business. Furthermore, 93\% of them stated that Facebook is the most applied platform in their business. In the survey, Twitter took second place; 79\% of marketers use it for business purposes. Youtube is also a platform among the top five social media platforms applied by commercial organizations, according to research. Similar to the findings on commercial institutions, Thomson et al. (2013) identified the three most commonly adopted social media networks within the cultural sector - Facebook, Twitter and Youtube. Thus, the authors decided to investigate the state of social media presence in museums, exploring their activities on the three most popular social media networks among cultural institutions. Subjects of the study are museums from two neighboring countries, considering their geographic and historic bond - Czech Republic and Germany. The different political, 
economic and cultural statuses may provide additional insights on the dependence of such variables on the propensity towards social media application by specific sector. The cases studied in the research are Berlin and Prague museums, being representatives of the two regions located in two capitals. In light of the absence of previous studies, the paper examines the level of museum participation in social media, and the level at which they use an integrative approach in social media communication with audiences relative to simultaneous application of the most popular social media networks worldwide. Additionally, the current situation on integrative social media approach by Berlin and Prague museums, and its implication on museums public relation efforts, provides the base for more specific studies that will be conducted in the future.

The research is structured as follows. We present current issues related to the field of social media opportunities in respect to their marketing and managerial implications to the business processes. The following section delineates goals and methodologies applied in the study, subsequently presenting the findings and a discussion of results. Finally, we conclude the study providing the state of social media presence of Berlin and Prague museums on Facebook, Twitter and Youtube. Additionally, we identify weak points and provide suggestions for future research. In this regard, all the museums in Berlin and Prague are subjects of the study, identified by official institutions in both regions.

\section{Theoretical Background}

\subsection{Introduction to Social Media}

The idea of the World Wide Web was originally introduced in 1989 by Burners-Lee, who imagined it as a large structure for information exchange with the purpose to upgrade human cooperation, communication and cognition. The concept of WWW should not be mistaken for the Internet but it certainly is the most recognizable part of the Internet. During its evolution and development, the Web has undergone several transitions in the paradigm and relationship between actors. The term Web 2.0 was firstly presented by Dougherty in 2004. The new approach introduced a paradigm-shift by focusing on enhanced interactivity and bidirectional communication. Furthermore, it would support bi-directional creation, exchange and sharing of content among the users, shifting the focus from one-to-many to many-to-many based communication (Dougherty, 2004).

The terms Web 2.0 and social media have been used interchangeably by some authors. Kelly (2009: 2) defined the term of social media as "...the tools and platforms people use to publish, converse and share content online. The tools include blogs, wikis, podcast, and sites to share photos and bookmarks. An important component of social media is the idea of social networking".

The reach of social media has had exponential growth. Statista (2015) claims the total number of social network users in the world was 1.79 billion at the end of 2014, predicting at the same time, an increase in the numbers up to 2.44 billion users in 2018 . Currently, the most popular social media platform is Facebook with 1.42 billion, and $38.6 \%$ of global online population using Facebook.

The Pew Research Center (2015) identifies the most dominant demographic group involved with Facebook worldwide - pointing at $82 \%$ of online adults with the age between 18 and 29 that use Facebook, and 79\% of those with the age ranging between 30-49. The situation is similar with Twitter, considering the demographics, numbering 32\% and 29\% 
of online adults respectively. According to the study by the same institution in $2011,71 \%$ of online adults watch videos on a video-sharing sites such as Youtube, adding the group between 18 and 29 years to be the most active with $92 \%$ of Internet users belonging to this category. The second dominant category, with $80 \%$ of online population, are those ranging between 30 and 49 years.

\subsection{The State of Social Media within Museum Sector}

Arts Council England, MLA and Arts \& Business (2010) conducted research on the national level, identifying the importance of social media involvement by art and culture institutions. Online audiences, according to the study, are actively involved with digital media while at the same time, the main motives to involve with these networks are identified as: access, learning, experience, sharing and creation. The study indicates that in today's digital environment, it is not enough for museums to only participate in the social media world, but they should also be actively involved with a specific social media strategy. This would positively affect the needs of online audiences for two-way communication, while further steps to improve the dialogue would develop the relationship between audiences and museums. To date, there is no research on a common measure that evaluates social media strategy. However, there are clear suggestions in the literature that every institution, aiming to take the best out of social media opportunities, should define a social media strategy according to its specific goals and manage a proficient team to lead the strategy. In participation throughout online conversations, museums should focus on the three general points of a successful social media strategy: to listen to the conversation, to learn from it and join in the conversation according to what has been learned (Ektron, 2009). Chung et al (2014) suggest strategies that could improve museums relationship with audiences, focusing mainly on the importance of building the awareness strategy, the comprehension strategy and the engagement strategy.

Thomson et al. (2013) conducted research within the sector of USA arts organizations, defining the main implication of social media marketing among them. The aim of social media in this regard is as follows. The first on the list is to promote the arts, then to increase the audience involvement, to use the organization's resources more efficiently, to enable organizations to engage in art advocacy more efficiently, to provide arts education to the public and enable artistic collaboration, as well as to improve various management requests. Additionally, literature identifies that social media improves and develops productive and long-lasting relationships with audiences and helps in achieving competitive advantages together with the fulfilment of museums' social role (Simon 2007; Wright and Hinson 2008). The importance of a long-term relationship and loyalty in the online environment is also mentioned by authors (Tahal, 2014).

The Australian Council for the Arts in 2011 defined key opportunities for arts organizations and how they should develop their online presence. These consider getting the attention of audiences, building word of mouth, engaging the audiences and enriching their experience, building an integrated strategy for the above mentioned variables, making easier public access to events and following audiences' needs by means of the Internet. In this regard, word of mouth can be distinguished as a tool to influence the opinions of others and to affect the image of a museum. Developing an appropriate strategy means discovering optimal tools for effective motivation and influence on audiences (Hausmann, 2012; Evans, 2008). 
The literature mainly considers marketing effects of social media application by museums. Recognized by authors today, social media is a tool that may utilize the dialogue between museums and their audiences (Hausmann, 2012; Tasich and Villaespesa; 2013). Managing the communication between audiences and organizations is the function of public relations, in the general sense (Grunig and Hunt, 1984).

\subsection{The Advantages of Social Media Application by Museums}

The authors identified various positive effects of the development of an individual social media strategy by museums. Social media represents a multi-way communication model that provides museums with the opportunity to positively influence active participation not only of the museums but their visitors as well (Fletcher and Lee, 2012). Additionally, the restriction that the majority of museums face corresponds to insufficient funds and restricted resources. Considering this fact, social media has been recognized as a tool that may provide great benefits with the use of limited resources (Hausmann, 2012). Moreover, some authors recognized social media's capacity to reach a wider range of audiences, in comparison to the conventional channels (Kotler and Armstrong, 2009). These networks are also beneficial in advocating institutions and their causes (Kelleher, 2006).

The literature not only focuses on the benefits of application of an individual social media platform, but it also highlights advantages of the simultaneous application of various social media platforms at the same time. However, only a few studies have been undertaken so far, to extend the understanding of how the strategy developed around these networks could positively affect relationship development with audiences. In this regard, Pett (2012) focused his research on marketing effects of social media strategy, one that creates a successful online brand. Tasich and Villaespesa (2013) recognize social media platforms as tools that may provide an improved dialogue between museums and their audiences. Moreover, Russo and Watkins (2007) propose other ways museums could use social media platforms. These directions of social media application correspond to sharing information, responding to issues that become important in the relationship between museums and audiences, and the creation of new knowledge.

Kaplan and Haenlein (2010) suggest the integration of social media as a key point to success. The integration may expand the reach of the message broadcast by the organization. In a survey conducted with visitors to nine online museums, Marty (2007) indicates that after a visit to a museum, audiences regularly visit the museum's Webpage to enhance the experience they got from physical visit to the museum.

\subsection{Czech and German Online Population}

Internet World Stats (2014) provides data on Internet penetration in Germany and Czech Republic, identifying the level of online audiences among the population as $86.2 \%$ in Germany and 74.1\% in Czech Republic. At the same time, the larger base of Facebook audiences, among online audiences, is recorded as $36.1 \%$ in the Czech Republic and $31.3 \%$ in Germany (Facebook penetration). Recent studies evidence the growing trend in social media usage among Internet users in Germany. The study conducted by Busemann registered that from 2008 to 2013, the number of social media users increased by $36.6 \%$. German Social Media Consumer Report (2013) provides data on the favorite social 
media platforms in the country. ${ }^{1}$ Facebook access on a daily basis is done by $77 \%$ of Internet users. Twitter and Youtube are visited by $45.10 \%$ and $41.6 \%$ online audiences, respectively.

World Internet Project research on Czech Republic (2014) identifies an increase of Internet users by one third since 2005 . The study concerns the population older than 15 years, and identifies the fastest growing trend with the group of unemployed, pensioners and employees. Two-thirds of non-users are those aged 65 or older. Czech users spend their online time involved in online communication and social networking sites.

\subsection{Museums in Czech Republic and Germany}

The International Council of Museums (ICOM) defines museums as "a noncommercial, permanent institution in the service of society and of its development, and open to the public, which acquires, conserves, researches, communicates and exhibits, for purposes of study, education and enjoyment, material evidence of man and his environment".

On the bases of the defined criteria, the European Group on Museums Statistics - EGMUS (2014) provides the data on museums statistics across European museums, and identifies the presence of 486 museums in the Czech region, and 6,372 museums in Germany. It further develops the three main categories of museums: art, archeology and history museums; science and technology museums, ethnology museums; other museums (p.141). According to the criteria developed around these types of museums, in 2014 EGMUS identified 101 Czech and 1,155 German art, archeology and history museums. Further, it reported that Czech Republic has 50 science and technology and ethnology museums. In Germany, the second category of museums is not applicable as science and technology museums are split from ethnology museums. For this reason, EGMUS categorize 5,217 museums in Germany to be in the third category. For the purpose of this research, the authors apply the study to the two main categories of museums: art, archeology and history, and other museums.

\section{Methods}

The goal of the research is to provide an understanding of museums' online social networking presence. Facebook, Twitter and Youtube have been chosen as reference online social networks, considering the fact that these represent one of the most proliferated and adopted social media networks today (Statista, 2015); they are also the top three rated social media networks used by arts institutions according to Thomson et al. (2013).

The main objective of the study is to analyze the Web and online social network presence of Berlin and Prague museums. The study aims to consider museums' activity on Facebook, Twitter and Youtube, and to identify the level of simultaneous application of the most popular social media networks by museums. The subsequent goal is to examine which type of museums is most present on social media networks. Museums are classified according to the criterion defined by European Group on Museums Statistics.

The research examines the social media presence among all the museums in Berlin and Prague. The study is undertaken on the sample of 296 museums from both regions, listed by officially acclaimed institutions - Museums Portal Berlin and

$1 \quad n=2474$ users 
Association of Museums and Galleries of Czech Republic. The data collected present museums' social media activity for the months of 2014 - February, March and April. 4 Findings

The section presents results of the data collected on Berlin and Prague museums' activities in the Web and Facebook online space, which is comprised of two main parts.

\subsection{Web and Facebook Presence of Museums}

The Figure 1 represents the quantitative ratio of Web and Facebook presence among Berlin and Prague museums.

Figure 1 | Web and Social media presence of Berlin and Prague museums

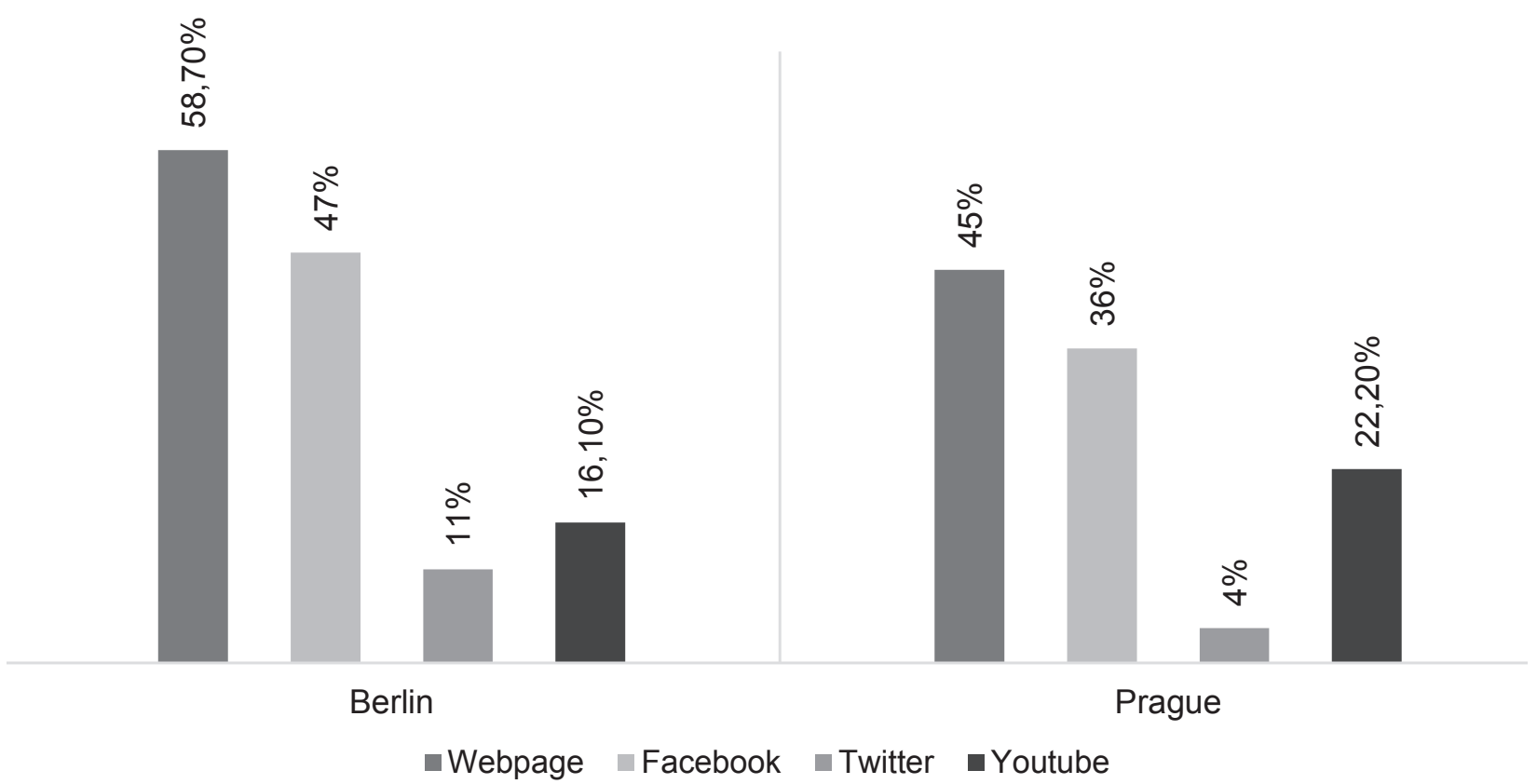

Source: Authors

In Berlin $58.7 \%$ museums run a web page and $47.4 \%$ of them simultaneously have an active Facebook profile. The investigation on Twitter and Youtube presence is done on the sample of museums that are present on Facebook. In the case of Berlin museums, only $22.5 \%$ museums simultaneously apply Twitter and $16.1 \%$ Youtube. Museums in Prague tend to exhibit online presence to a lesser extent than Berlin museums. Among all of Prague's museums, 36\% of them manage a Facebook profile, while $45 \%$ provide an organizational web page. Also, $11.1 \%$ and $22.2 \%$ have a Twitter and Youtube account besides their Facebook profile.

A minor number of museums simultaneously provide a Twitter and Youtube profile, next to their Facebook account. In Berlin, only eight museums manage profiles on all three networks, while in Prague this situation is characteristic only to one museum.

Based on the starting point - the absolute number of museums present on web and online social networks - the two cities differ two-fold. The disparity however continues to propagate and even grow in the next steps. Thus, the aggregate absolute number of Facebook fans is near to a 5 -fold variance, which may be affected on the basis of demographic differences. The other metrics, average and median followers per institution, 
suggest a misbalance to a lesser extent. Namely, Prague institutions demonstrate on average and approximately nearly one-half less Facebook fans and Twitter followers. Additionally, the difference on the bases of the number of Youtube subscribers is nearly 3-fold, on average. Although Prague museums score higher, in the average number of museums using Youtube channel simultaneously with Facebook account, they lack with regard to the number of subscribers on the network.

Table 1 | Followers on social media networks by museum organizations from both cities

\begin{tabular}{|l|c|c|c|c|c|c|}
\hline & \multicolumn{3}{|c|}{ Prague } & \multicolumn{3}{c|}{ Berlin } \\
\cline { 2 - 7 } & Facebook & Twitter & Youtube & Facebook & Twitter & Youtube \\
\hline Total & 106,471 & 3,926 & 425 & 498,870 & 34,367 & 3,088 \\
\hline Average & 2,958 & 982 & 12 & 5,364 & 1,637 & 35 \\
\hline Median & 902 & 941 & 0 & 1,884 & 1,426 & 0 \\
\hline
\end{tabular}

Source: Authors

\section{2 | Frequency of Activity}

The number of institutions that did not post a single post on their Facebook wall during the research period is at similar levels in both cities - namely, $11 \%$ of Berlin museums and $12 \%$ of Prague museums. Out of this number, the majority had less than 1000 fans. This suggests that the number of fans is affected by the level of museums activity on Facebook.

Berlin museums posted 1,695 tweets and 1,451 Facebook post. Total reactions attracted by museums' activity is larger with Facebook posts than with tweets $-27,869$ Facebook posts against 2,464 tweets. On average, every Facebook post collects 15 reactions, and tweets only one reaction. Berlin museums post, on average, every fifth to sixth day, and tweet every day.

Prague museums posted 571 Facebook posts and 149 tweets; 4,963 reactions of the audiences are induced by Facebook posts, and 193 by tweets. Every Facebook post brings nine reactions, and a single tweet collects two reactions. Prague museums publish a Facebook post every fifth to sixth day, and tweet on every second to third day, on average.

The number of published posts on Twitter is about 10 times larger in the case of Berlin museums comparing to their counterparts, in absolute metrics. When the activity on Twitter is considered on an average basis, Berlin museums record nearly a two-fold higher level of published posts. On average, Berlin museums posted a tweet every day during the observed period. Prague museums posted a tweet every other day, on average.

In comparison to the Facebook activity, we conclude that both Berlin and Prague museums are more active on their Twitter social media platform.

On average, the Facebook activity of Berlin museums attracted two times more reactions of their online audience than Prague museums, although the institutions from both cities posted the same average number of messages on the platform. The larger base of fans by Berlin museums may influenced the score, but also attractiveness 
of the published messages and diverse other factors could impact this tendency. In absolute metrics, the number of reactions resulting from the published tweets is 10 times larger in the case of Berlin museums than Prague institutions. The amount of difference mainly arises out of the number of museums presented on Twitter. In average terms, the reactions collected per museums are two-times larger in favor of Berlin museums. However, comparing the average number of reactions collected by a single post published by museums, more reactions are attracted with Prague museums - namely two reactions per tweet, in comparison to one reaction collected by a tweet published by Berlin museum.

Applying the EGMUS museum classification, the study identifies 70 out of 93 (75.2\%) German museums with a Facebook account fall into the first category - art, archeology and history museums. Fourteen museums are scientific and technology museums, and nine are other types of museums. In Czech Republic, 29 out of 36 museums $(80.6 \%)$ are art, archeology and history museums. Five museums that provide a Facebook profile are science and technology, and ethnology museums, and only two are from the group of other museums.

Seventy-six percent of German museums that simultaneously provide a Twitter account, besides a Facebook profile, are in the category of art, archeology and history museums. In Czech Republic, all museums that have a Twitter profile besides Facebook are from the category of art, archeology and history museums.

\section{Discussion of Results}

In the previous section we provided an overview on the Web and social media presence among Berlin and Prague museums. The majority of museums in both groups provide an organizational Webpage, although Berlin museums are more active in terms of Web presence - near $60 \%$ among them having an official Webpage, on average. Among Prague museums, less than half of them have a Webpage. We identified that Berlin and Prague museums should significantly improve their Web presence, in relative terms. This is important for better utilization of audiences' needs, as these could be monitored through their Webpage. In this regard, Anderson (2004) suggests the indicator of the effectiveness of a social media strategy may be the number of Webpage visits. Berlin and Prague museums lack in the application of the measure, as a Webpage is a tool that may record the reactions of online audiences and provides insights on the level of their satisfaction by museums' collections and activities.

A similar level of presence is recorded by both neighboring regions on Facebook in relative terms, while the difference is recorded in the application of Twitter and Youtube platforms. In this regard, on average, Berlin museums are twice as active on Twitter but also, to a lesser extent, are present on Youtube channel, in comparison to Prague museums.

Simultaneous application of all the three social media networks is characteristic only to one museum in Prague, while in Berlin eight museums provide this type of integrative approach to social media strategy. Thus, the findings revealed not only a low application of social media platforms by museums of Berlin and Prague, but also the weak points of social media strategy developed by the simultaneous application of social media networks. Kaplan and Andreas (2010) suggest integration of media as a key element of social media success by organizations. As the study identified additional weak spots of 
social media strategy in both regions, we suggest a higher level of integrative strategy applied by both museums groups. This way, the message broadcasted may become more visible and the level of user engagement more activated. The suggestion is also supported by Smith and Mogos (2013) who investigated the effectiveness of social media on business performance, concluding that a combination of inter-linked social media may create a social media system that significantly improves business capabilities.

Additionally, both in absolute and average metrics, Berlin museums record larger fan bases in all the three social media networks - Facebook, Twitter and Youtube. Moreover, the highest level of disparity, in absolute terms, is recorded on the base of Twitter followers, where Berlin records nearly 10-fold more followers than Prague museums. This situation may be explained by the differences in the demographics and the number of active museums on Twitter. However, when relative metrics such as average number of followers are introduced, the observable is the difference to the lesser extent - Berlin museums attract only twice as many Twitter followers than Prague museums. Additionally, we identified that although Prague museums on average use Youtube channels more actively than Berlin museums, they attract fewer followers. This may result from the type of content used through museums Youtube communication with audiences.

Additionally, we identified that $11 \%$ and $12 \%$ of museums in Berlin and Prague, respectively, did not publish a single post on Facebook during the research period. Only providing a Facebook profile is not enough for institutions to provide better visibility and other advantages of social media application.

In addition, although Berlin museums record a similar level of activity as Prague museums on their Facebook profiles in relation to broadcasted posts, in average terms, they are more active than Prague museums on Twitter profiles. Not only the larger number of museums provide a Twitter account, but Berlin museums are twice as active on the channel and attract twice as many reactions from online audiences than Prague museums, in average terms.

The large majority of museums that provide a profile on a social media network are art, archaeology and history museums. Other type of museums, such as science, technology, ethnology and other museums have a minor presence on social media networks in both regions.

\section{Conclusion}

The paradigm of online social networks dramatically influenced the dimensions and quality of interaction between organizations and their customers. Although this concept already gained broad adoption in the general public and among commercial entities, its particular application in the area of cultural institutions is somewhat less and considered as weak.

This study has a purpose to fill the gap in analysis of the practical application of online social networking engagement among museums' institutions. This has been done through explorative and comparative empirical analysis of museums' social media practice in two dissimilar socio-eco-cultural areas of Europe. For the purposes of this study, Czech Republic and Germany were selected, with a focus on their capital cities, Prague and Berlin. The starting points of this analysis were 196 Berlin and 100 Prague museums, of which 93 Berlin and 36 Prague institutions were present on Facebook, representing the sample for subsequent analysis considering simultaneous application of Twitter and Youtube. 
The analysis of museums' involvement with social media networks revealed that, in absolute terms, Berlin museums were more involved online than their peers in Prague. They demonstrated a higher level of activity considering the dimensions of Web page, Facebook, Twitter and Youtube presence. However, the Youtube platform is more popular with Prague museums than Berlin museums, in relative terms.

Considering relative values, although Prague museums demonstrated a similar level of posting frequency, their Berlin peers delivered higher impact in the terms of user engagement. However, the research identified a multidirectional gap in the social media strategy of both groups of museums. Berlin and Prague museums not only record a low level of Facebook, Twitter and Youtube presence, they also do not optimally apply an integrative social media strategy, one that would incorporate a simultaneous application of more social media channels beside their presence on the most proliferated social media network - Facebook.

Everything being said, museums should establish a Facebook profile which is regularly updated and managed on a daily basis. The content posted should be interesting enough to reach the attention of fans and motivate them to interact by creating content which would not only increase the rate of its attraction to fans but stimulate them to share it and comment on it. The following recommendation considers their simultaneous application of more social media in their social media policy. An integrative social media strategy may impact a museum's brand image and have a positive effect on the development of bidirectional dialogue with online visitors, which subsequently may improve their public relations strategy effects.

The future research could involve investigations on the specific strategy all the museums use in a single social media platform. This should cover the broad range of semantic and technical features of published posts by museums. The way they communicate with online audiences, the structure of broadcasted messages and the deeper understanding of the mechanisms of online audience engagement could help to widen the scope of comprehension of how the weak spots of social media strategy applied by museums may be improved. Additionally, future research may involve all museums in the whole national region of investigated museums. Considering the implications on the general overview of the state of social media strategy by museums in regions, we also find that the investigation of the outliers may uncover a deeper understanding of the effects of social media adaptation on online audiences.

\section{References}

Anderson, M. L. (2004). Metrics of success in art museums. Los Angeles, CA: Getty Leadership Institute.

Arts Council England, MLA and Arts \& Business (2010). Digital audiences: engagement with arts and culture online. Retrieved February 5, 2016 from http://creative-blueprint.co.uk/ library/item/digital-audiences.

Black, G. (2005). The Engaging Museum: Developing Museums for Visitor Involvement. New York: Routledge.

Bocatius, B. (2011). Education and learning in Museums 2.0-German Museums and the Web 2.0. Kunstgeschichte. Open Peer Reviewed Journal. 
Boyd, D. (2008). Facebook's Privacy Trainwreck. Convergence: The International Journal of Research into New Media Technologies, 14(1), 13-20.

Boyd, D., \& Ellison, N. (2008). Social Network Sites: Definition, History and Scholarship. Journal of Computer-Mediated Communication, 13, 210-230.

Chung, T. L., Marcketti, S., \& Fiore, A. M. (2014). Use of social networking services for marketing art museums. Museum Management and Curatorship, 29(2), 188-205.

Drotner, K., \& Schrøder, K.C. (2013). Museum Communication and Social Media: The Connected Museum. New York: Taylor and Francis.

Ektron (2009). Social media strategy: Word-of-mouth marketing for the digital age. White Paper, 10.

Evans, D. (2008). Social Media Marketing: An Hour a Day. Indiana: Wiley Publishing Inc.

Evans, D. (2010). Social Media Marketing: The Next Generation of Business Engagement. New Jersey: John Wiley \& Sons.

Fletcher, A., \& Lee, J. M. (2012). Current Social Media Uses and Evaluations in American Museums. Museum Management and Curatorship, 27(5), 505-521.

Social Media Think Lab (2013). German Social Media Consumer Report 2012/2013. Marketing Center Muenster and Roland Berger Strategy Consultants.

Hausman, A. (2012). The Importance of Word of Mouth for Museums: An Analytical Framework. International Journal of Arts Management, 14(3), 32-43.

Kaplan, A. M., \& Haenlein, M. (2010). Users of the World, Unite! The Challenges and Opportunities of Social Media. Business Horizons, 53(1), 59-68.

Kelly, L. (2009). The Impact of Social Media on Museum Practice. National Palace Museum, Taipei, 20.

Kidd, J. (2011). Enacting Engagement Online: Framing Social Media Use for the Museum. Information Technology \& People, 24(1), 64-77.

Kidd, J. (2014). Museums in the New Mediascape: Transmedia, Participation, Ethics. Surrey: Ashgate Publishing, Ltd.

López, X., Margapoti, I., Maragliano, R., \& Bove G. (2010). The Presence of Web 2.0 Tools on Museum Websites: A Comparative Study Between England, France, Spain, Italy, and the USA. Museum Management and Curatorship, 25(2), 235-249.

Sareh, A., Nematbakhsh, M.A., \& Khosravi Farsani, H. (2012). Evolution of the World Wide Web: From Web 1.0 To Web 4.0. International Journal of Web \&Semantic Technology, 3(1), 1-10.

Simon, N. (2007). Discourse in the Blogosphere: What Museums Can Learn from Web 2.0. Museums \& Social Issues, 2(2), 257-274.

Smith, M. \& Mogos, S. (2013). The impact of Social Media on Business Performance. ECIS 2013 Completed Research. Paper 125.

Social Media Marketing Industry Report (2015). Social Media Examiner. Retrieved December 17, 2015 from http://www.socialmediaexaminer.com/report/.

Statista (2015). Number of monthly active Facebook users worldwide as of 4th quarter 2015. Retrieved November 5, 2014 from http://www.statista.com/statistics/264810/ number-of-monthly-active-facebook-users-worldwide.

Tahal, R. (2014). Loyalty Programs in E-commerce and their Perception by the Young Adult Internet Population. Central European Business Review, 2(3), 7-13. 
Thomson, K., Purcell, K., \& Rainie, L. (2013). Arts organizations and digital technologies, Pew Research Center, Retrieved December 12, 2015 from http://www.pewinternet. org/2013/01/04/arts-organizations-and-digital-technologies/.

Wong, S. A. (2011). Ethical Issues of Social Media in Museums: A Case Study. Museum Management and Curatorship, 26(2), 97-112.

Wright, K. D., \& Hinson, M. D. (2008). How Blogs and Social Media are Changing Public Relations and the Way It Is Practiced. Public Relations Journal, 2(2).

Zarrella, D. (2010). The Social Media Marketing Book. Sebastopol, CA: O'Reilly Media Inc.

Weinberg, T. (2009). The New Community Rules: Marketing on the Social Web. Sebastopol, CA: O'Reilly Media Inc.

\section{Authors}

\section{Ing. Bojana Suzić}

Department of Marketing

Faculty of Business Administration

University of Economics, Prague

W. Churchill Sq. 4, 13067 Prague, Czech Republic

bojanasuzic@gmail.com

\section{doc. Ing. Miroslav Karlíček, Ph.D.}

Head of Marketing Department

Department of Marketing

Faculty of Business Administration

University of Economics, Prague

W. Churchill Sq. 4, 13067 Prague, Czech Republic

miroslav.karlicek@vse.cz

doc. Ing. Václav Stříteský, Ph.D.

Associate Professor

Department of Marketing

Faculty of Business Administration

University of Economics, Prague

W. Churchill Sq. 4, 13067 Prague, Czech Republic

vaclav.stritesky@vse.cz 